\title{
Exploring Learners' Developing L2 Collocational Competence
}

\author{
Supakorn Phoocharoensil \\ Thammasat University, Bangkok, Thailand
}

\begin{abstract}
This research study was aimed at an investigation of Thai EFL learners' collocational competence, with focus on the problems in their collocation use. The data, elicited from essays written by two groups of participants with different $\mathrm{L} 2$ proficiency levels, are indicative of actual problems with which the learners are really confronted. With respect to the sources of these collocational errors, native language transfer seems to be the most important contributing factor. Where the collocations in L1 Thai and L2 English are incongruent, deviations often arise. The interlingual errors found pertain to preposition addition, preposition omission, incorrect word choice, and collocate redundancy. It is worth noticing that the high-proficiency learners heavily depend on collocational patterns from their mother tongue, to which low-proficiency students are expected to resort. In addition to $\mathrm{L} 1$ transfer, the participants also seem to rely on synonymy and overgeneralization, both of which result in erroneous collocations in English.
\end{abstract}

Index Terms - collocation, collocational competence, English learners, difficulty and errors, language transfer

\section{INTRODUCTION}

English learners, no matter to what context of learning they belong, e.g. EFL, ESL, or EIL, have difficulty acquiring second language (L2) vocabulary. Not merely are they supposed to learn the meaning(s) of a new word in English, but it is also of paramount importance to know what possible words can co-occur with it (Lewis, 2000; Nation, 2008). Such neighboring words in combination with their node word are known as collocation, i.e. the term originally introduced by Firth (1957) to refer to a combination of words associated with each other. Frequency of co-occurrence seems to be the crucial factor in determining whether a combination should be treated as a collocation, as Lewis (2000, p. 8) defines collocation as "the readily observable phenomenon whereby certain words co-occur in natural text with greater than random frequency"

According to Nation and Webb (2011), multiword units, which include collocation, play a very significant role in both language use and language learning. A large proportion of English that learners meet and use in real English are composed of these lexical bundles or chunks (Biber, Conrad and Cortes, 2004). As a result, learners' effective L2 English comprehension and production can be facilitated by the knowledge of the frequent multiword units. An incorporation of collocation into English language curricula is now and will be inevitable; furthermore, research on multiword units "will continue to be a central area of research for both curriculum design and language learning theory and practice" (Nation and Webb, 2011, p. 175).

There have apparently existed a great number of research studies so far on the collocational knowledge of English learners speaking many different native or first languages (L1). Nonetheless, research on Thai EFL students' ability to use collocations is limited to a single group of learners, especially those with high-proficiency level, e.g. English-major students (e.g. Boonyasaquan, 2006; Mallikamas and Pongpairoj, 2005; Mongkolchai, 2008). The present study with a cross-sectional design was aimed at bridging this gap through focusing on two groups of learners whose proficiency levels are different in order for the researcher to compare their interlanguage collocational competence (Ellis, 2008), with an emphasis on an exploration and explanation of the areas of difficulty confronting the students.

The next section reviews the related literature as well as previous empirical studies on L2 English collocation acquisition.

\section{REVIEW OF LITERATURE}

\section{A. Defining Collocation}

The term collocation was coined by Firth (1957), as previously stated, who remarked, "collocations of a given word are statements of the habitual or customary places of that word" (p. 181). According to McCarthy (1990), collocation constitutes a relationship which is "a marriage contact between words, and some words are more firmly married to each other than others" (p. 12). Sinclair (1990) refers to collocations as "items that occur physically together or have stronger chances of being mentioned together" (p. 170). For Lewis (2000), collocations occur in a statistically significant way, and Hill (2000) suggests that some collocations are predictable, e.g. the verb foot, which has a strong tendency to cooccur or collocate with the object noun bill, as in foot the bill. It is worth noticing that the term collocation may also be interchangeably used with others, e.g. formulaic language, chunks, multiword units, lexical bundles, prefabricated 
routines (Wray, 2002). It is the focus of researchers' analysis that determines the choice of term (Schmitt, 2010).

\section{B. Collocation Types}

The current study uses Benson, Benson, and Ilson (1997)'s collocation classification: lexical collocations and grammatical collocations. Lexical collocations are normally made up of two or more content words, i.e. nouns, verbs, adjectives, and adverbs, as shown below:

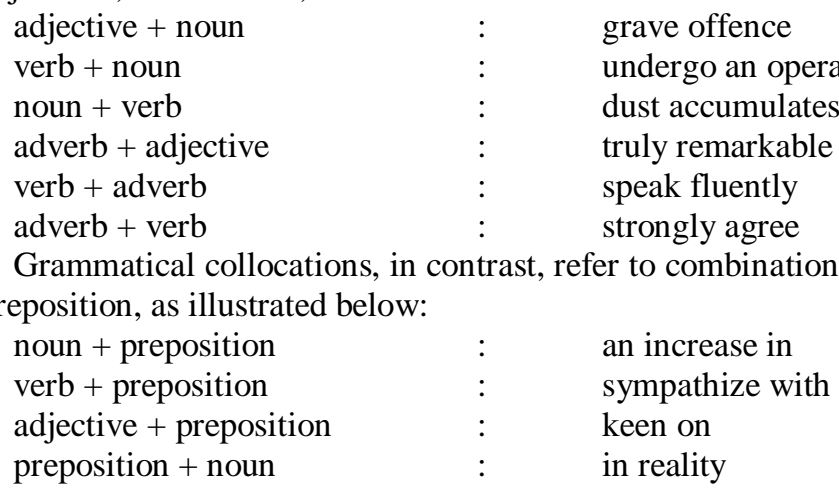

\section{Significance of Collocations in English Learning}

English learners need to include collocations as a part of vocabulary learning (Hill and Lewis, 1997). Likewise, teachers should take collocations as a major component to be put into their English language curriculum for several reasons. First of all, Erman and Warren (2000) discovered 58.6\% of multiword units in spoken English discourse and $52.3 \%$ in written counterpart. This is also consistent with Carter, McCarthy, Mark, and O'keeffe (2011), who reported on a large number of collocating words existing in all languages. Another major reason is that collocations allow learners to process L2 more easily and efficiently. Willis (2003) maintained that, unlike native speakers, who constantly recognize multiword units, e.g. collocations, and use language naturally at high speed, non-native speakers often process L2 word-by word due to a shortage of ready-made chunks or collocations in vocabulary. In other words, as noted by Pawley and Syder (1983), the use of stored multiword units like collocations leads to native-like fluency and accuracy.

\section{Previous Relevant Studies on L2 English Collocation Acquisition}

Many past research studies have indicated that English learners employ certain learning strategies in their acquisition of English collocations. The most frequent strategy on which they depend concerns first language (L1) transfer. As stated by Swan (1997), learners' L2 vocabulary learning is often influenced by their native language since they compensate for a lack of L2 lexical knowledge. A lot of research findings lent support to Swan's claim. However, transfer from native language can result in an unpleasant or incorrect use of vocabulary in the target language.

Bahns and Eldaw (1993) revealed that L1 influence was present in the interlanguage of German learners of English. Asked to translate sentences from German into English, the participants heavily relied upon their mother tongue, producing L2 combinations that reflected L1 traces, although resorting to L1 could occasionally become effective where L2 collocations have L1 equivalents. Nesselhauf (2003), in a similar vein, accorded with Bahns and Eldaw (1993) in that influence from L1 German was highly noticeable in their collocation use. Such L1 transfer was often a cause of interlingual errors in the target language when collocations in L1 and L2 are non-congruent. Her view is that teachers are expected to highlight non-congruent collocations between L1 and L2 in their lessons in order that this should prevent students from creating L1-based unacceptable English collocational patterns.

Koya (2003), measuring 93 Japanese learners of English's receptive and productive knowledge of English collocations, focused on the use of noun-verb collocations. According to the study, although it was hypothesized that the low-proficiency learners were likely to resort to L1 collocational knowledge, it turned out to be opposite since the learners with high proficiency rather than the low-proficiency ones apparently relied on L1 collocations, especially in their production. Those whose proficiency was lower seemed to apply an avoidance strategy, refraining from giving any answer to almost all the questions which have no direct translation from L1 Japanese.

Boonyasaquan (2006) examined Thai EFL learners' collocational violations in translating a Thai business article into English. The participants were recruited from 32 fourth-year English majors from a university in Bangkok. The scope of the study was eight patterns of collocations: adjective + noun, verb + noun, noun + noun, verb + adverb/ adverb + verb, adverb + adjective, noun + verb, verb + preposition, and preposition + noun. The highest frequency of collocational violations fell on the adjective + noun pattern $(21.31 \%)$. The analysis of the violations indicated that the influence from the learners' native language was one of the most common sources of errors. An example of interference errors given by the researcher is *expensive price, which is probably derived from direct translation from the Thai combination of

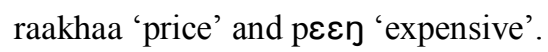

Strong evidence of L1 influence on L2 English collocation use was given by Laufer and Waldman (2011)'s study, in which Hebrew learners of English at three proficiency levels produced collocations indicative of native language 
transfer. More specifically, the study revealed that approximately half of deviant collocations seemed to stem from L1 influence, and these errors did not tend to decline over time. It was likely that the learners, in contrast to native English speakers, construct messages from individual words rather than from prefabricated units or formulaic sequences, depending on L1 transfer and having tendency to ignore restrictions on word combinations.

Another research study that looked at EFL learners' use of English collocations is Phoocharoensil (2011). In the study, the data were elicited from Thai EFL undergraduate students' descriptive essays. It was revealed that lexical collocations posed more serious problems for the students than did grammatical ones. More specifically, among all the lexical collocation types, the verb-noun combinations appeared to be the most difficult for both upper-intermediate and lower-intermediate learners. The most problematic kind of grammatical collocations, as suggested by the upperintermediate learners' writing, was verb-preposition and preposition-noun collocations, while those with the lowerintermediate level were evidently most troubled with verb-preposition collocations. With respect to the sources of errors the students produced L2 English collocations using L1 transfer as the most common learning strategy, which resulted in deviations, such as preposition omission, preposition insertion, and incorrect choice of preposition.

Interference from learners' L1 was also clearly seen in collocational errors in Iranian postgraduate students' academic writings, as shown by Namvar, Nor, Ibrahim, and Mustafa (2012). The study found that L1 Persian caused the participants to erroneously use English collocations. Apart from L1 transfer, L1-L2 cultural differences evidently played a part in collocation difficulty they were faced with.

Another learning strategy frequently adopted in L2 collocation acquisition is associated with synonymy, i.e. a type of an analogy made by learners having limited L2 collocational ability or low exposure to the target language collocations. According to Biber, Conrad, and Reppen (1998, p.43), synonyms are typically used in different ways. That is to say, despite sharing a similar meaning, synonyms cannot be always used interchangeably in all contexts. Synonyms in English, in particular, can also be distinguished by looking at which lexical collocates are possible for which particular synonymous word. In other words, with regard to making a distinction between synonyms, "it is often how the words collocate with other words that can show up differences." (McCarthy, O'Keeffe, and Walsh, 2010, p. 32). For instance, according to the 50-million-word sample of the Bank of English corpus, which is made up of English magazines, even though the synonyms strong and powerful can be interchangeable in some collocations, e.g. strong/ power leader, strong/ power voice, or strong/powerful argument, etc., they cannot be substituted for each other in some others, e.g. strong views (but not *powerful views), or powerful computer (but not *strong computer) (McCarthy, O'Keeffe, and Walsh, 2010).

It should be clear that word choice is heavily constrained by what comes before or after in the context, i.e. collocation. As noted by Thornbury (2002, p. 7), "Even the slightest adjustments to the collocations - by substituting one of its components for a near synonym...- turns the text into non-standard English".

Many studies in L2 acquisition of English collocations have shown that synonymy is often used as a common learning strategy. In Farghal and Obiedat (1995), the use of synonyms by Arabic EFL learners was examined. It was revealed that the learners heavily relied on the open choice principle for word selection, substituting a synonym for a word, which often led to deviant and ungrammatical collocations in English. In a similar vein, Howarth (1996, 1998) has demonstrated that analogy such as using synonyms can be regarded as a form of intralingual L2 transfer. Learners are very productive when they count on analogy. Nonetheless, this strategy sometimes causes them to produce erroneous collocations, e.g. *adopt ways, which was possibly produced by analogy with adopt an approach (Howarth, 1998, p. 41).

Furthermore, Zughoul and Abdul-Fattah (2001) discovered assumed synonymy in the use of English collocations by Arabic speakers. In this research, owing to the nature of the instructional input which the learners received at school and the impact of bilingual dictionaries, the participants' collocation production based on replacing a word with a synonym or a near synonym that does not conform to the existing collocates seemed to be unacceptable, violating the selectional restrictions in L2. For instance, they used the verb failed as opposed to defeated in the sentence *The enemy was failed in the battle, causing a semantically ill-formed construction. Zughoul and Abdul-Fattah's (2001) discovery of synonymy as a strategy to learn collocations is consistent with Zughoul (1991), who has found that learners, when translating from Arabic to English, seemed to be greatly dependent on bilingual dictionaries which merely give a list of synonyms with no sample sentences or explanations for their different uses. Thus, this may account for the fact that learners may write *a qualified hotel instead of a quality hotel (Zughoul, 1991), as cited in Boonyasaquan (2006, p. 83), assuming that the adjectives qualified and quality can be used interchangeably in every context.

Another study that reported on synonymy as a major cause of collocational errors is Guo (2009). The participants of this study, i.e. Taiwanese EFL learners who majored in English, failed in observe the collocability of some English synonyms, producing miscollocations, e.g. *receive an opinion, as opposed to the target-like combination accept an opinion.

As shown in a corpus-based study of written Malaysian English by Hong, Rahim, Hua, and Salehuddin (2011), in a similar way, Malaysian ESL students committed errors in verb-noun English collocations, relying on the synonymy strategy. The application of the learning strategy perhaps results from the learners' faulty comprehension of word distinctions in L2. That is, the students apparently used near-synonymous words interchangeably regardless of the collocability and contexts in which these words can occur. The confusion over English synonym use probably 
contributes to the incorrect collocations.

As for research investigating Thai EFL learners' collocational knowledge, Boonyasaquan (2006) has found that Thai learners, in translating a business news article from Thai to English, incorrectly applied the strategy of synonymy, equal to $8.62 \%$ of all the possible sources of collocational violations. Another study that lent support to Boonyasaquan (2006) in terms of synonymy is Mongkolchai (2008). According to Mongkolchai (2008), the participants committed collocational errors when they applied the strategy of synonymy. For instance, a noun + noun combination such as *a newspaper booth was supplied in their translation, despite the fact that a newspaper kiosk instead has been found in native speakers' corpora. In addition, Thai undergraduate students in Phoocharoensil (2011)' study were also found to adopt synonymy by inappropriately replacing a word with its synonym that does not fit in the context of use. For instance, they used peaceable when peaceful was probably intended.

In the following section, the research method used in the current study is comprehensively described.

\section{Methodology}

\section{A. Population and Sample}

The population of the current research study was first-year undergraduate Thai students at Thammasat University. As regards sampling, stratified random sampling was used to obtain 90 Thai EFL learners from different faculties to participate in the study. They were divided into two groups of 45: high $(\mathrm{H})$ and low $(\mathrm{L})$, according to their English proficiency. The participants, recruited from various faculties, were taking an English foundation course in the second semester of Academic Year 2010. The 45 high-proficiency learners registered for English Course 3 (EL 172), whereas the other 45 with lower proficiency took English Course 2 (EL 171). Each group was assigned by Thammasat Registration Office to a separate section. Such a section assignment has enabled the researcher to randomly choose to teach and collect data from any two groups of different proficiency levels.

In terms of subject classification, the learners were assigned to two different English courses based on the O-NET scores. The O-NET is the University Entrance Exam endorsed by the Ministry of Education of Thailand to assess 12thgraders English competency. This test, launched in 2006, is recognized as a standardized test designed and validated by scholars from National Institute of Educational Testing Service (N-IETS) of Thailand (www.niets.or.th). The participants whose O-NET scores ranged from 69 to 80 were assigned to EL 172 and thus regarded as high-proficiency learners. In contrast, those whose scores were between 32 and 56 registered for EL 171 and they were classified as lowproficiency learners.

The participants' mother tongue was Thai, and they had learned English as a foreign language for at least 12 years. Those who studied in an international secondary school, who were bilingual, or who stayed in an English-speaking country for more than three consecutive months were excluded from the present study because their high English proficiency may not truly reflect the interlanguage of Thai EFL learners in general.

\section{B. Research Instruments}

As the present study was aimed at investigating Thai learners' written production of English collocations, the research tool selected is a descriptive essay. This particular kind of essay, compared to other categories, has been shown to contain a wealth of modifications usually formed by word combinations (Langan, 2009). For this reason, it is a descriptive essay that is the most likely to elicit various types of collocations, e.g. adjective + noun, noun + verb, verb + noun, verb + preposition, preposition + noun, etc.

Another reason why a descriptive essay was employed for the data elicitation lies in the fact that it is expected to reflect the way learners really use collocations in English since they would not be forced to produce word combinations, unlike when they perform some other tasks, e.g. a gap-filling test, a cloze test, an error-correction test, or a translation task, which are relatively controlled in nature.

With respect to the learners' knowledge of English writing, all first-year university students are supposed to have had at least some basic paragraph-writing skill from the secondary level as writing has been incorporated into the secondary-school English curriculum since 2008 (www.moe.go.th). This means the participants should know what a good-quality English paragraph looks like.

In the process of data collection, the learners were asked to write the essay in class within 60 minutes. They were also informed that their work would not be graded according to grammatical correctness. In other words, they should feel free to naturally produce the written task which represents their actual collocational competence.

\section{Data Collection}

The data collection was carried out in two phases:

(1) Regarding the participant recruitment, 90 first-year undergraduate students from different faculties at Thammasat University were randomly selected and assigned to two proficiency groups based on their O-NET scores, as mentioned earlier.

(2) Each of the participants was asked to write a 200-word descriptive essay on a topic which was considered easy and possible for them to discuss in writing. Each of the essays was supposed to comprise an introductory paragraph, two or more body paragraphs, and a concluding paragraph. The writing process took place within 60 minutes in a classroom 
setting, where the learners were not permitted to consult any kind of references. Neither were they allowed to ask the teacher for any advice on language use, e.g. grammar, vocabulary, etc. However, because the students were aware that their written task would not be assessed on the basis of grammatical correctness, the end products should represent their genuine ability to use English collocations.

\section{FINDINGS AND DisCUSSION}

\section{Causes of Collocational Problems}

As clearly shown in the collocations used by both groups of participants, two major learning strategies in connection with cognitive processes were employed (Selinker, 1992) were employed, unfortunately often causing unacceptable combinations in the target language. The strategy adopted by most participants in collocation learning was L1 transfer, followed by synonymy

Native language transfer

The data indicated that Thai EFL students often depended upon collocational patterns in L1, thus frequently transferring an equivalent from Thai to English. Unfortunately, where collocational incongruence between Thai and English exists, errors usually result. The first type of error related to L1 influence concerns preposition use. The learners omitted a preposition after a verb or a preposition, perhaps resulting from literal translation from L1 Thai. as in (1)-(3).

(1)* I will wait her at my house.

(2) * She lied me many time, so I would not believe her anymore.

(3) * He was suddenly angry me when he knew the truth.

The error in (1) occurs due to the fact that the English verb wait, always subcategorizing for the preposition for, cannot be followed by a noun or pronoun, e.g. her, while its equivalent in Thai, or ros 'wait', requires a direct object (Panthumetha, 1982). In a similar way, the verb lied in (2), grammatically speaking, needs the following preposition to instead of an object like me in (2). The students might have transferred from L1 Thai syntactic knowledge in which kohok 'lie' is a transitive verb, which normally occurs right before a direct object. Furthermore, an omission of an obligatory preposition was also discovered in Thai EFL learners' collocations when the adjective angry was used immediately before the object pronoun $m e$ in (3), which leads to ungrammaticality in L2 English. To rectify this error, the preposition with needs to be added after angry. In fact, krot 'angry' in L1 Thai can be followed by a noun or noun phrase, which may influence Thai learners to ignore the fact that there, in English, should be a preposition like with after angry.

The subjects of the study, in addition, added an unnecessary preposition to a verb. This type of deviation arises when a verb in Thai needs to precede a prepositional phrase, while its English counterpart requires a direct object. The discrepancy as such may result in the learners' preposition addition in L2 English, as in (4) below.

(4) * His laziness affected to his final grades.

The verb-preposition combination of affected to in (4) may also stem from L1 Thai influence. That is, the verb sòppǒn 'affect' in Thai often precedes the preposition $t 5 j^{\circ}$ 'to', which was probably why some Thai learners inserted the preposition to right after this verb.

Another kind of interlingual collocational error regarding preposition use deals with an incorrect choice of preposition, as can be seen in (5)-(6)

(5) * Our friends really loved the new teacher. In the other hand, Pom showed his bad attitude to her.

(6) * In the same time, my sister was cooking our breakfast.

The problems in (5) and (6) are associated with wrong choices of preposition. In particular, the preposition in in (5), rather than on, was used to mistakenly construct the transitional expression In the other hand. It is probable that the students literally translated from the Thai phrase nai ìk $\eta \varepsilon \hat{\varepsilon}$ n’̀n, where naI 'in' has been transferred to the problematic L2 English combination. Similar to (5), the erroneous combination in (6) results from the misuse of in, as opposed to at, due to the fact that the learners probably depended on the L1 Thai collocational pattern naI wee laa diow kan 'at the same time'.

(7) * The new room we will move stays at Khlong Song.

In addition to the aforementioned errors on prepositions, Thai EFL learners apparently relied on L1 transfer in nounverb collocation production. In (7), the unnatural noun + verb chunk is clearly similar to a corresponding construction in L1 Thai. To be more precise, in Thai, when a place is being referred to, the verb yùu 'stay or live' often co-occurs with the preposition thîi 'at', as in yùu thîi 'be located at/in' (Phoocharoensil, 2011). Thai students, particularly those with inadequate English proficiency, are likely to transfer such a verb phrase in Thai to L2 English, thereby constructing a mis-collocation.

(8) * He plays cellphone even in classroom.

The collocational deviations in (9) should also stem from L1 transfer. In Thai, using the verb len 'play' with words like torasàp 'telephone', intənèt 'the Internet' and khompýwtəે 'computer' is common (Phoocharoensil, 2011). This may be a reason why Thai EFL students with limited L2 English competence created the erroneous combination play 
cellphone, which appeared to result from L1 transfer.

In summary, L1 influence is evidently the most common strategy on which Thai students rely in collocation production in L2 English. Thai EFL learners often resort to L1 collocational patterns when they cannot find the appropriate content words, i.e. nouns, verbs, and adjectives, or function words, e.g. preposition, in the target language (Phoocharoensil, 2011, 2013). Transfer from learners' mother tongue often results in collocational deviations in the target language. The study also reveals that not only do students with limited L2 competency level are influenced by L1 collocational patterns, but also the students with high-proficiency also used English collocations based on L1 collocational counterparts. This provides support for Koya (2003), who surprisingly discovered that even highproficiency Japanese EFL learners were inclined to depend upon native language in finding collocations for L2.

The fact that L1-Thai speakers transferred collocations from L1 Thai to L2 English, as indicated by the present-study results, gives support to past studies on second language acquisition of L2 English collocations (e.g. Bahn and Eldaw, 1993; Boonyasaquan, 2006; Koya, 2003; Laufer and Waldman, 2011; Phoocharoensil, 2011, 2013; Mongkolchai, 2008)

In the next part, synonymy, i.e., another collocation-learning strategy which the participants employed, is discussed in detail.

Synonymy

The Thai students in the present study evidently used synonymy in English collocation learning. Simply put, they appeared to replace a word with another having a similar meaning. Although doing so may sometimes be successful, most studies reveal a drawback of such a strategy (e.g. Boonyasaquan, 2006; Howarth, 1996; 1998; Mongkolchai, 2008).

As shown in the data, the participants relied on synonymy as a strategy for using collocations in English. In particular, this learning strategy was employed more in lexical collocations than in grammatical counterparts, which found support for Phoocharoensil (2011). (9)-(11) below illustrate lexical errors caused by synonymy.

(9) * They will try every way to reach their goal in the end.

(10) * The cost of all the ingredients will reduce by more than $50 \%$.

(11) * Mei asked me to reply the phone for her because she didn't want to hear her boyfriend's voice.

The erroneous combination reach their goal in (9) seems to stem from Thai EFL learners' application of synonymy strategy. In other words, while it is possible for reach one's target, it sounds inappropriate to use reach one's goal (McCarthy and O'Dell, 2008) despite the fact that target and goal are synonyms. The restriction on word choice to constitute native-like collocation in English is apparently arbitrary. This may explain why even high-proficiency learners, like those in the present study, were found to become easily confused over when to use or not to use which word, thus ending up substituting a synonym for a vocabulary item, which leads to an erroneous L2 collocational pattern.

In (10), the participants, it is very likely, misused the verb reduce due to some confusion caused by different uses of English synonyms. According to Longman dictionary of contemporary English (2009), reduce is a transitive verb, which must be followed by a direct object. On the other hand, other synonyms of reduce like decrease or decline do not have the same usage. They, in other words, are usually used as intransitive verbs, not requiring any following object. It is evident that although reduce, decrease, and decline are similar in certain semantic aspects, they differ in syntactic patterns. Actually the error in (10) apparently stems from the use of reduce as if it were functioning as an intransitive verb, whereas more appropriate intransitive verbs in this context should be decrease or decline.

The source of error in (11) also pertains to a synonymy strategy. That is to say, the verb-noun collocation reply the phone does not appear to suitably construct a collocation in English. Even though answer and reply are semantically related in some respects, they cannot be used interchangeably in all contexts. To be more specific, it is undeniable that the verb answer collocates perfectly with the following noun phone, whilst reply does not. Instead, the verb phrase reply to often co-occurs with words, such as letter, term, plea, debate, person, etc., as indicated by British National Corpus (BNC) data.

Apart from the use of synonymy in learning English lexical collocations, this strategy seemed to be applied in grammatical collocation production, as seen in (12).

(12) * We gave the present for our teacher.

The occurrence of the preposition for in (12) does not form a target-like collocation with the verb gave. In actuality, the verb give requires an object noun phrase and a prepositional phrase introduced by to, as in give something to someone (Longman dictionary of contemporary English, 2009, p. 738). Presumably, the non-target like lexical chunk in (12) may be caused by learners' lack of knowledge on the appropriate use of the synonyms give and provide. Whilst give should be used with the preposition to, provide often occurs in the pattern provide something for someone. Such a difference in terms of preposition use may explain why EFL learners easily become confused about the usage of the two verbs.

The application of synonymy by Thai EFL learners rely is consistent with many past studies on English collocation learning (e.g. Howarth, 1996, 1998; Zughol and Abdul-Fattah, 2001). The results accord with the past studies on Thai learners as well (e.g. Boonyasaquan, 2006; Mongkolchai, 2008; Phoocharoensil, 2011, 2013), which reported on collocational deviations resulting from synonymy.

\section{Pedagogical Implications}


The findings of this research study pinpoint the collocational problems arising from Thai EFL learners' application of certain learning strategies. Not only do such strategies contribute to Thai students' problems, but also other EFL learners speaking other L1s frequently suffer from similar difficulty of English collocation acquisition, as these strategies have been apparently widely adopted across EFL learners as well (e.g. Farghal and Obiedat, 1995; Howarth, 1996, 1998; Nesselhauf, 2003, 2005; Mongkolchai, 2008). For this reason, EFL teachers may find the results of this study useful, and they are advised to highlight the notion of collocation in vocabulary classrooms, as "this is globally accepted as an essential element in EFL vocabulary curricula" (Nation, 2008, as cited in Phoocharoensil, 2013).

More importantly, teachers can also help prevent students from inappropriately applying strategies with regard to collocation learning. For instance, teachers may clearly compare and contrast different usages of some sample pairs of synonyms, making it a point to them that words being semantically close are hardly interchangeable in all contexts. Moreover, teachers whose L1 is the same as the students', e.g. Thai, should provide a list of common English L2 collocations that differ from L1 counterparts, which could, to a certain extent, help learners become aware of a mismatch between collocations in both languages (Nesselhauf, 2003, as cited in Phoocharoensil, 2013). Put differently, it is necessary for learners to know that dependence on L1 collocational knowledge can result in collocational deviations in L2. As Nation (2008, p. 121) claimed, a L2 multi-word unit that does not have an L1 equivalent has "to be met and remembered", whereas teachers do not seem to emphasize deliberate collocation learning and teaching where a perfect match between L1 and L2 collocational patterns exists. Likewise, an explicit explanation of L1-L2 differences for certain collocations and even translating such collocations when necessary sometimes yields a more pleasant result than other teaching methods that ignore the cross-linguistic differences (Phoocharoensil, 2013).

\section{REFERENCES}

[1] Bahns, J. \& Eldaw, M. (1993). Should we teach EFL students collocations? System, 1(1), 101-114.

[2] Benson, M., Benson, E., \& Ilson, R. (1997). The BBI dictionary of English word combinations. Amsterdam: John Benjamins.

[3] Biber, D., Conrad, S., \& Cortes, (2004). If you look at...: Lexical bundles in university teaching and textbooks. Applied Linguistics, 25(3), 371-405

[4] Biber, D., Conrad, S., \& Reppen., R. (1998). Corpus linguistics: Investigating language structure and use. Cambridge: Cambridge University Press

[5] Boonyasaquan, S. (2006). An analysis of collocational violations in translation. Journal of Humanities, 27, 79-91. Bangkok: Faculty of Humanity, Srinakharinwirot University.

[6] Carter, R., McCarthy, M., Mark, G., \& O’Keeffe, A. (2011). English grammar today: An A-Z of spoken and written grammar. Cambridge: Cambridge University Press.

[7] Ellis, R. (2008). The study of second language acquisition. Oxford: Oxford University Press.

[8] Erman, B. \& Warren, B. (2000). The idiom principle and the open choice principle. Text, 20, 29-62.

[9] Farghal, M. \& Obiedat, H. (1995). Collocations: A neglected variable in EFL. International Review of Applied Linguistics in Language teaching, 33(4), 315-531.

[10] Firth, J. R. (1957). Papers in linguistics, 1934-1951. Oxford: Oxford University Press.

[11] Guo, C. (2009). An analysis of the use of collocations by intermediate EFL college students in Taiwan. ARECLS, 6, 141-155.

[12] Hill, J. (2000). Revisiting priorities: From grammatical failure to collocational success. In M. Lewis (Ed.), Teaching collocation: Further development in the lexical approach (pp. 47-69). London: Commercial Colour Press Plc.

[13] Hill, J., \& Lewis, M. (1997). LTP dictionary of selected collocations. Hove: Language Teaching Publications.

[14] Hong, A. L., Rahim, H. A., Hua, T. K., \& Salehuddin, K. (2011). Collocations in Malaysian English learners' writing: A corpus-based error analysis. The Southeast Asian Journal of English Language Studies, 17, 31-44.

[15] Howarth, P. (1996). Phraseology in English academic writing. Some implications for language learning and dictionary making. Tübingen: Niemeyer.

[16] Howarth, P. (1998). Phraseology and second language proficiency. Applied Linguistics, 19, 45-72.

[17] Koya, T. (2003). A study of collocation in English and Japanese noun-verb combinations. Intercultural Communication Studies, XII-1, 125-145.

[18] Langan, J. (2009). College writing skills. New York: The McGraw-Hill Companies.

[19] Laufer, B. \& Waldman, T. (2011). Verb-noun collocations in second language writing: A corpus analysis of learners' English. Language Learning, 61(2), 647-672.

[20] Lewis, M. (2000). Teaching Collocation: Further Developments in the Lexical Approach. Hove, English: Language Teaching Publications.

[21] Longman dictionary of contemporary English $5^{\text {th }}$ edition (2009). Essex: Pearson Education Ltd.

[22] Mallikamas, P. \& Pongpairoj, N. (2005). Thai learners' knowledge of English collocations. HKBU Papers in Applied Language Studies, 9, 1-28.

[23] McCarthy, M. (1990). Vocabulary. Oxford: Oxford University Press.

[24] McCarthy, M. \& O’Dell, F. (2008). Academic vocabulary in use. Cambridge: Cambridge University Press

[25] McCarthy, M., O’Keeffe, \& Walsh, S. (2010). Vocabulary matrix. Understanding, learning, teaching. Hamshire: Heinle Cengage Learning.

[26] Mongkolchai, A. (2008). A study of university students' ability in using English collocations. Master's project. Srinakharinwirot University.

[27] Namvar, F, Nor, N. F. M, Ibrahim, N, \& Mustafa, J. (2012). Analysis of collocations in the Iranian postgraduate students' writings. 3L: Language, Linguistics, Literature. The Southeast Asian Journal of English Language Studies, 18(1), 11-22.

[28] Nation, I. S. P. (2008). Teaching vocabulary. Strategies and techniques. Boston, MA: Heinle Cengage Learning. 
[29] Nation, I.S.P. \& Webb, S. (2011). Researching and Analyzing Vocabulary. Boston, MA: Heinle

[30] Nesselhauf, N. (2003). The use of collocations by advanced learners of English and some implications for teaching. Applied Linguistics, 24(2), 223-242.

[31] Nesselhauf, N. (2005). Collocations in a learner corpus. Amsterdam: John Benjamins.

[32] Panthumetha, N. (1982). Thai Grammar. Bangkok: Chulalongkorn University Press.

[33] Pawley, A. \& Syder, F. (1983). Two puzzles for linguistic theory: Nativelike selection and nativelike fluency. In J. C. Richards \& N. Schmitt (Eds.), Language and communication (pp. 191-225). London: Longman.

[34] Phoocharoensil, S. (2011). Collocational errors in EFL learners' interlanguage. Journal of Education and Practice, 2(3), 103120.

[35] Phoocharoensil, S. (2013). Cross-linguistic influence: Its impact on L2 English collocation production. English Language Teaching, 6(1), 1-10.

[36] Schmitt, N. (2010). Researching vocabulary. A vocabulary research manual. London: Palgrave Macmillan

[37] Selinker, L. (1992). Rediscovering interlanguage. London: Longman.

[38] Sinclair, J. (1990). Corpus concordance collocation. Oxford: Oxford University Press.

[39] Swan, M. (1997). The influence of the mother tongue on second language vocabulary. In N. Schmitt \& M. McCarthy (Eds.), Vocabulary: Description, acquisition, and pedagogy (pp. 40-63). Cambridge: Cambridge University Press.

[40] Willis, D. (2003). Rules, patterns, and words. Grammar and lexis in English language teaching. Cambridge: Cambridge University Press.

[41] Wray, A. (2002). Formulaic language and the lexicon. Cambridge: Cambridge University Press.

[42] Zughoul, M. R. \& Abdul-Fattah, H. S. (2001). Collocational competence of Arabic speaking learners of English: A study in lexical semantics. $\quad$ Retrieved $\quad$ April $\quad 8, \quad 2010$ from.http://eric.ed.gov/ERICDocs/data/ericdocs2sql/content_storage_01/0000019b/80/1b/4f/28.pdf.

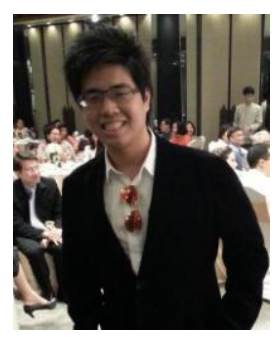

Supakorn Phoocharoensil is an Assistant Professor at Language Institute of Thammasat University. His areas of research specialization include second language acquisition of English lexis and syntax, interlanguage pragmatics, and corpus linguistics. He had his research articles published in a number of international peerreviewed journals, e.g. The Journal of Pan-Pacific Association of Applied Linguistics, Hong Kong Journal of Applied Linguistics, International Journal of Research Studies in Language Learning, The Southeast Asian Journal of English Language Studies, The International Journal of Learning, etc. 